\title{
Commentary: Ex Situ Aqueous Mineral Carbonation
}

\author{
Greeshma Gadikota* \\ Department of Civil and Environmental Engineering, Princeton University, Princeton, NJ, USA
}

Keywords: mineral carbonation, carbon mineralization, $\mathrm{CO}_{2}$ conversion, utilization and storage, magnesium and calcium silicates, magnesium and calcium carbonates, alkaline industrial wastes

\section{A commentary on}

Ex Situ Aqueous Mineral Carbonation

by Gerdemann, S. J., O'Connor, W. K., Dahlin, D. C., Penner, L. R., and Rush, H. (2007). Environ. Sci. Technol. 41, 2587-2593. doi: 10.1021/es0619253

$\mathrm{CO}_{2}$ conversion to calcium and magnesium carbonates has garnered considerable attention since it is a thermodynamically downhill pathway to safely and permanently sequester large quantities of $\mathrm{CO}_{2}$. This seminal work performed at The National Energy Technology Laboratory in Albany (NETL-Albany) reports the conversion of calcium- and magnesium-bearing silicate minerals, such as olivine $\left[(\mathrm{Mg}, \mathrm{Fe})_{2} \mathrm{SiO}_{4}\right]$, wollastonite $\left(\mathrm{CaSiO}_{3}\right)$, and serpentine $\left[\mathrm{Mg}_{3} \mathrm{Si}_{2} \mathrm{O}_{5}(\mathrm{OH})_{4}\right]$, as they are reacted with $\mathrm{CO}_{2}$ in an aqueous environment to form magnesium or calcium carbonates. This paper discusses various pretreatment methods of the starting materials, such as grinding or heat treatment of hydroxylated $\mathrm{Mg}$ silicates, to enhance the reaction kinetics. The effects of various chemical additives (e.g., $\mathrm{NaCl}$ and $\mathrm{NaHCO}_{3}$ ), and reaction parameters, such as temperature, pressure, and reaction time, on the conversion are investigated. Feasibility assessments and energy and economic analyses of the direct carbonation of calcium- and magnesium-bearing minerals are presented.

The key contributions of this study are the identification of the optimal conditions for the carbonation of olivine $\left(185^{\circ} \mathrm{C}, \mathrm{P}_{\mathrm{CO}_{2}}=150 \mathrm{~atm}, 1.0 \mathrm{M} \cdot \mathrm{NaCl}+0.64 \mathrm{M} \cdot \mathrm{NaHCO}_{3}\right)$, wollastonite $\left(100^{\circ} \mathrm{C}, \mathrm{P}_{\mathrm{CO}_{2}}=40 \mathrm{~atm}\right.$, distilled water $)$, and heat-treated serpentine $\left(155^{\circ} \mathrm{C}, \mathrm{P}_{\mathrm{CO}_{2}}=150 \mathrm{~atm}\right.$, $\left.1.0 \mathrm{M} \cdot \mathrm{NaCl}+0.64 \mathrm{M} \cdot \mathrm{NaHCO}_{3}\right)$. High extents of carbonation of $49.5,81.8$, and $73.5 \%$ of olivine, wollastonite, and heat-treated serpentine, respectively, achieved within an hour of reacting with $\mathrm{CO}_{2}$ in an aqueous environment are reported. The identification of the optimal reaction conditions to achieve the rapid conversion of calcium- and magnesium-bearing silicate minerals to carbonates has spurred a significant global scientific interest in mineral carbonation as a promising technology for $\mathrm{CO}_{2}$ conversion and storage with the potential reuse of carbonates.

In particular, this work has found unique relevance for ex situ and in situ carbon mineralization. In ex situ mineral carbonation, $\mathrm{CO}_{2}$ is converted to carbonates in engineered processes where there is considerable control over the reaction conditions. In in situ mineral carbonation, $\mathrm{CO}_{2}$ is injected into geological formations containing calcium- and magnesium-bearing minerals and rocks with the aim toward natural carbon mineralization over time. Predicting the fate of $\mathrm{CO}_{2}$ injected into geological formations containing these rocks and minerals and developing chemical processes for converting $\mathrm{CO}_{2}$ to carbonates require a fundamental understanding of the kinetics of mineral carbonation and the corresponding morphological changes in materials. Thus, more recent studies have focused on understanding the carbon mineralization behavior via direct carbonation (Bonfils et al., 2012; Gadikota et al., 2014a; Eikeland et al., 2015) and indirect carbonation, which involves the dissolution of minerals (Park et al., 2003; Park and Fan, 2004; Hänchen et al., 2006; Prigiobbe et al., 2009; Gadikota et al., 2014b), formation of carbonates (Ferrini et al., 2009; Saldi et al., 2009, 2012; Cheng and Li, 2010; Bénézeth et al., 2011; Zhao et al., 2013; Fricker and Park, 2014; Swanson 
et al., 2014), and the corresponding morphological changes in materials (Hövelmann et al., 2012; Olsson et al., 2012; Gadikota et al., 2014a). The effects of sodium and ammonium salts and $\mathrm{Si}-$, Mg-, and Ca-targeting chelating agents on enhancing mineral carbonation behavior has been investigated (Bonfils et al., 2012; Highfield et al., 2012; Declercq et al., 2013; Zhao et al., 2013; Gadikota et al., 2014a,b; Ghoorah et al., 2014).

These studies have formed the basis for understanding $\mathrm{CO}_{2}$ interactions with calcium and magnesium silicates that extend beyond the laboratory to the demonstration scale (Reddy et al., 2010; Kelly et al., 2011; Zevenhoven et al., 2011; Hitch and Dipple, 2012; Brent, 2015) and toward geological carbon storage (Kelemen and Matter, 2008; Matter and Kelemen, 2009; Schaef and McGrail, 2009; Gislason et al., 2010; Rosenbauer et al., 2012). The studies performed at NETL-Albany have also been extensively cited in studies for the accelerated carbonation of industrial alkaline wastes [Pan et al. (2012), Gadikota and Park (2014), Sanna et al. (2012), and references contained therein]. These materials are often fine, highly reactive, and have a high $\mathrm{Ca}$ and $\mathrm{Mg}$ content. Examples of these materials include coal fly ash, steel and stainless steel slags, cement and lime kiln dusts, and red mud. However, the availability of industrial alkaline wastes is much smaller compared to calcium- and magnesium-bearing silicate minerals. The global $\mathrm{CO}_{2}$ storage potential of industrial alkaline wastes is about 200-300 Mt of $\mathrm{CO}_{2}$ per year, while calcium- and magnesium-bearing silicates can store carbon to the order of thousands of Gt (Sanna et al., 2012). Regardless, the integration of carbon mineralization technologies with these carbonintensive industries reduces the $\mathrm{CO}_{2}$ footprint, the alkalinity of the wastes, and could lead to the potential reuse of the carbonated materials as building, construction, or filler materials. Further development of carbon mineralization technologies requires a fundamental understanding of the formation of mass transfer limiting layers containing Si and Fe (Béarat et al., 2006; King et al., 2010; Daval et al., 2011; Saldi et al., 2013, 2015; Sissmann et al., 2013; Harrison et al., 2015), linkages between the morphology with the chemistry (Hövelmann et al., 2012; Olsson et al., 2012; Gadikota et al., 2014a; Eikeland et al., 2015), and the impact of impurities in the gas streams (e.g., $\mathrm{SO}_{2}$ ) on the conversion of $\mathrm{CO}_{2}$ to carbonates (Liu et al., 2010; Zevenhoven et al., 2014). While

\section{REFERENCES}

Béarat, H., McKelvy, M. J., Chizmeshya, D., Gormley, A. V., Nunez, R., Carpenter, R. W., et al. (2006). Carbon sequestration via aqueous olivine mineral carbonation: role of passivating layer formation. Environ. Sci. Technol. 40, 4802-4808. doi:10.1021/es0523340

Bénézeth, P., Saldi, G. D., Dandurand, J.-L., and Schott, J. (2011). Experimental determination of the solubility product of magnesite at 50 to $200^{\circ} \mathrm{C}$. Chem. Geol. 286, 21-31. doi:10.1016/j.chemgeo.2011.04.016

Bonfils, B., Julcour-Lebigue, C., Guyot, F., Bodénan, F., Chiquet, P., and Bourgeois, F. (2012). Comprehensive analysis of direct aqueous mineral carbonation using dissolution enhancing organic additives. Int. J. Greenhouse Gas Control 9, 334-346. doi:10.1016/j.ijggc.2012.05.009

Brent, G. F. (2015). "Mineral carbonation of serpentinite: from the laboratory to pilot scale - the MCi project," in Accelerated Carbonation for Environmental and Material Engineering (New York City).

Cheng, W., and Li, Z. (2010). Controlled supersaturation precipitation of hydromagnesite for the $\mathrm{MgCl}_{2}-\mathrm{Na}_{2} \mathrm{CO}_{3}$ system at elevated temperatures: chemical these findings are in the context of ex situ mineral carbonation, they are of relevance to in situ conversion of $\mathrm{CO}_{2}$ to carbonates.

When $\mathrm{CO}_{2}$ is directly injected into geological reservoirs with calcium- and magnesium-bearing silicates, carbonate formation is aided by the geothermal gradient, which provides reaction temperatures in excess of $80^{\circ} \mathrm{C}, \mathrm{P}_{\mathrm{CO}_{2}} \sim 80-150$ bar available post-combustion and compression, and the presence of ground water. These conditions are analogous to the reaction conditions identified in this study. Of particular interest are the Oman peridotite (olivine-rich rock) (Kelemen and Matter, 2008; Matter and Kelemen, 2009) and the basalts in Iceland and Columbia River in the United States (Matter et al., 2009; McGrail et al., 2011). The chemomechanical effects due to extensive carbonate growth may induce microfractures, which in turn impact the permeability, fluid flow, and further reactivity of the rock (Kelemen et al., 2013). Regardless, the permanent in situ conversion of $\mathrm{CO}_{2}$ to carbonates reduces the need to monitor mobile $\mathrm{CO}_{2}$ over time.

While the experimental methodologies developed by the researchers at NETL-Albany have laid the foundation for a number of studies in this field, considerable uncertainties in the energy requirements for mineral carbonation exist. These uncertainties are attributed to some key parameters, such as the availability and cost of the feedstock, preprocessing of the materials, such as crushing and grinding, the conversion routes, and the use of heat vs. electricity. Regardless, the work performed at NETL-Albany has highlighted the need for a multi-scale understanding of the kinetics, mass transfer behaviors, competing reactions, and microstructural and chemical changes in heterogeneous materials, when reacted with $\mathrm{CO}_{2}$. These insights can be used to tune the reactivity and morphology of the carbonated end-materials. Ultimately, a fundamental understanding of $\mathrm{CO}_{2}$-reaction fluidmineral/rock interactions is essential for developing large-scale chemical processes for converting $\mathrm{CO}_{2}$ to carbonates, and for predicting the fate of $\mathrm{CO}_{2}$ injected into geological formations containing calcium and magnesium silicate minerals and rocks.

\section{AUTHOR CONTRIBUTIONS}

The author confirms being the sole contributor of this work and approved it for publication.

modeling and experiment. Ind. Eng. Chem. Res. 49, 1964-1974. doi:10.1021/ ie9015073

Daval, D., Sissmann, O., Menguy, N., Saldi, G. D., Guyot, F., Martinez, I., et al. (2011). Influence of amorphous silica layer formation on the dissolution rate of olivine at $90^{\circ} \mathrm{C}$ and elevated $\mathrm{pCO}_{2}$. Chem. Geol. 284, 193-209. doi:10.1016/j. chemgeo.2011.02.021

Declercq, J., Bosc, O., and Oelkers, E. H. (2013). Do organic ligands affect forsterite dissolution rates? Appl. Geochem. 39, 69-77. doi:10.1016/j.apgeochem.2013.09.020

Eikeland, E., Blichfeld, A. B., Tyrsted, C., Jensen, A., and Iversen, B. B. (2015). Optimized carbonation of magnesium silicate mineral for $\mathrm{CO}_{2}$ storage. ACS Appl. Mater. Interfaces 7, 5258-5264. doi:10.1021/am508432w

Ferrini, V., De Vito, C., and Mignardi, S. (2009). Synthesis of nesquehonite by reaction of gaseous $\mathrm{CO}_{2}$ with $\mathrm{Mg}$ chloride solution: its potential role in the sequestration of carbon dioxide. J. Hazard. Mater. 168, 832-837. doi:10.1016/j. jhazmat.2009.02.103

Fricker, K. J., and Park, A. H. A. (2014). Investigation of the different carbonate phases and their formation kinetics during $\mathrm{Mg}(\mathrm{OH})_{2}$ slurry carbonation. Ind. Eng. Chem. Res. 53, 18170-18179. doi:10.1021/ie503131s 
Gadikota, G., Matter, J., Kelemen, P. B., and Park, A. H. A. (2014a). Chemical and morphological changes during olivine carbonation for $\mathrm{CO}_{2}$ storage in the presence of $\mathrm{NaCl}$ and $\mathrm{NaHCO}_{3}$. Phys. Chem. Chem. Phys. 16, 4679-4693. doi:10.1039/c3cp54903h

Gadikota, G., Swanson, E. J., Zhao, H., and Park, A. H. A. (2014b). Experimental design and data analysis for accurate estimation of reaction kinetics and conversion for carbon mineralization. Ind. Eng. Chem. Res. 53, 6664-6676. doi:10.1021/ie500393h

Gadikota, G., and Park, A.-H. A. (2014). "Accelerated carbonation of Ca- and Mg-bearing minerals and industrial wastes using $\mathrm{CO}_{2}$," in Carbon Dioxide Utilization: Closing the Carbon Cycle, 1st Edn, eds P. Styring and A. Quadrelli (Elsevier), 115-134.

Ghoorah, M., Dlugogorski, B. Z., Balucan, R. D., and Kennedy, E. M. (2014). Selection of acid for weak acid processing of wollastonite for mineralisation of $\mathrm{CO}_{2}$. Fuel 122, 277-286. doi:10.1016/j.fuel.2014.01.015

Gislason, S. R., Wolff-Boenisch, D., Stefansson, A., Oelkers, E. H., Gunnlaugsson, E., Sigurdardottir, H., et al. (2010). Mineral sequestration of carbon dioxide in basalt: a pre-injection overview of the CarbFix project. Int. J. Greenhouse Gas Control 4, 537-545. doi:10.1016/j.ijggc.2009.11.013

Hänchen, M., Prigiobbe, V., Storti, G., Seward, T. M., and Mazzotti, M. (2006). Dissolution kinetics of fosteritic olivine at $90-150^{\circ} \mathrm{C}$ including effects of the presence of $\mathrm{CO}_{2}$. Geochim. Cosmochim. Acta 70, 4403-4416. doi:10.1016/j. gca.2006.06.1560

Harrison, A. L., Dipple, G. M., Power, I. M., and Mayer, K. U. (2015). Influence of surface passivation and water content on mineral reactions in unsaturated porous media: implications for brucite carbonation and $\mathrm{CO}_{2}$ sequestration. Geochim. Cosmochim. Acta 148, 477-495. doi:10.1016/j.gca.2014.10.020

Highfield, J., Lim, H., Fagerlund, J., and Zevenhoven, R. (2012). Activation of serpentine for $\mathrm{CO}_{2}$ mineralization by flux extraction of soluble magnesium salts using ammonium sulfate. RSC Adv. 2, 6535-6541. doi:10.1039/c2ra01347a

Hitch, M., and Dipple, G. M. (2012). Economic feasibility and sensitivity analysis of integrating industrial-scale mineral carbonation into mining operations. Miner. Eng. 39, 268-275. doi:10.1016/j.mineng.2012.07.007

Hövelmann, J., Austrheim, H., and Jamtveit, B. (2012). Microstructure and porosity evolution during experimental carbonation of a natural peridotite. Chem. Geol. 334, 254-265. doi:10.1016/j.chemgeo.2012.10.025

Kelemen, P. B., and Matter, J. M. (2008). In situ carbonation of peridotite for $\mathrm{CO}_{2}$ storage. Proc. Natl. Acad. Sci. U.S.A. 105, 17295-17300. doi:10.1073/ pnas.0805794105

Kelemen, P. B., Savage, H., and Hirth, G. (2013). "Reaction-driven cracking during mineral hydration, carbonation and oxidation," in Poromechanics V: Proceedings of the Fifth Biot Conference on Poromechanics (Reston, VA: American Society of Civil Engineers), 823-826.

Kelly, K. E., Silcox, G. D., Sarofim, A. F., and Pershing, D. W. (2011). An evaluation of ex situ, industrial-scale, aqueous $\mathrm{CO}_{2}$ mineralization. Int. J. Greenhouse Gas Control 5, 1587-1595. doi:10.1016/j.ijggc.2011.09.005

King, H. E., Plümper, O., and Putnis, A. (2010). Effect of secondary phase formation on the carbonation of olivine. Environ. Sci. Technol. 44, 6503-6509. doi:10.1021/ es 9038193

Liu, C. F., Shih, S. M., and Huang, T. B. (2010). Effect of $\mathrm{SO}_{2}$ on the reaction of calcium hydroxide with $\mathrm{CO}_{2}$ at low temperatures. Ind. Eng. Chem. Res. 49, 9052-9057. doi:10.1021/ie100924z

Matter, J. M., Broecker, W. S., Stute, M., Gislason, S. R., Oelkers, E. H., Stefánsson, A., et al. (2009). Permanent carbon dioxide storage into basalt: the CarbFix Pilot Project, Iceland. Energy Proc. 1, 3641-3646. doi:10.1016/j.egypro.2009.02.160

Matter, J. M., and Kelemen, P. B. (2009). Permanent storage of carbon dioxide in geological reservoirs by mineral carbonation. Nat. Geosci. 2, 837-841. doi:10.1038/ngeo683

McGrail, B. P., Spane, F. A., Sullivan, E. C., Bacon, D. H., and Hund, G. (2011). The Wallula basalt sequestration pilot project. Energy Proc. 4, 5653-5660. doi:10.1016/j.egypro.2011.02.557

Olsson, J., Bovet, N., Makovicky, E., Bechgaard, K., Balogh, Z., and Stipp, S. L. S. (2012). Olivine reactivity with $\mathrm{CO}_{2}$ and $\mathrm{H}_{2} \mathrm{O}$ on a microscale: implications for carbon sequestration. Geochim. Cosmochim. Acta 77, 86-97. doi:10.1016/j. gca.2011.11.001

Pan, S. Y., Chang, E. E., and Chiang, P. C. (2012). $\mathrm{CO}_{2}$ capture by accelerated carbonation of alkaline wastes: a review on its principles and applications. Aerosol Air Qual. Res. 12, 770-791. doi:10.4209/aaqr.2012.06.0149
Park, A. H. A., and Fan, L.-S. (2004). $\mathrm{CO}_{2}$ mineral sequestration: physically activated dissolution of serpentine and $\mathrm{pH}$ swing process. Chem. Eng. Sci. 59, 5241-5247. doi:10.1016/j.ces.2004.09.008

Park, A. H. A., Jadhav, R., and Fan, L.-S. (2003). $\mathrm{CO}_{2}$ mineral sequestration?: chemically enhanced aqueous carbonation of serpentine. Can. J. Chem. Eng. 81, 885-890. doi:10.1002/cjce.5450810373

Prigiobbe, V., Costa, G., Baciocchi, R., Hänchen, M., and Mazzotti, M. (2009). The effect of $\mathrm{CO}_{2}$ and salinity on olivine dissolution kinetics at $120^{\circ} \mathrm{C}$. Chem. Eng. Sci. 64, 3510-3515. doi:10.1016/j.ces.2009.04.035

Reddy, K. J., Weber, H., Bhattacharyya, P., Argyle, M., Taylor, D., Christensen, M., et al. (2010). Instantaneous capture and mineralization of flue gas carbon dioxide: pilot scale study. Nat. Precedings. doi:10.1038/npre.2010.5404.1

Rosenbauer, R. J., Thomas, B., Bischoff, J. L., and Palandri, J. (2012). Carbon sequestration via reaction with basaltic rocks: geochemical modeling and experimental results. Geochim. Cosmochim. Acta 89, 116-133. doi:10.1016/j. gca.2012.04.042

Saldi, G. D., Daval, D., Guo, H., Guyot, F., Bernard, S., Le Guillou, C., et al. (2015). Mineralogical evolution of Fe-Si-rich layers at the olivine-water interface during carbonation reactions. Am. Mineral. 100, 2655-2669. doi:10.2138/ am-2015-5340

Saldi, G. D., Daval, D., Morvan, G., and Knauss, K. G. (2013). The role of Fe and redox conditions in olivine carbonation rates: an experimental study of the rate limiting reactions at 90 and $150^{\circ} \mathrm{C}$ in open and closed systems. Geochim. Cosmochim. Acta 118, 157-183. doi:10.1016/j.gca.2013.04.029

Saldi, G. D., Jordan, G., Schott, J., and Oelkers, E. H. (2009). Magnesite growth rates as a function of temperature and saturation state. Geochim. Cosmochim. Acta 73, 5646-5657. doi:10.1016/j.gca.2009.06.035

Saldi, G. D., Schott, J., Pokrovsky, O. S., Gautier, Q., and Oelkers, E. H. (2012). An experimental study of magnesite precipitation rates at neutral to alkaline conditions and $100-200^{\circ} \mathrm{C}$ as a function of $\mathrm{pH}$, aqueous solution composition and chemical affinity. Geochim. Cosmochim. Acta 83, 93-109. doi:10.1016/j. gca.2011.12.005

Sanna, A., Hall, M. R., and Maroto-Valer, M. (2012). Post-processing pathways in carbon capture and storage by mineral carbonation (CCSM) towards the introduction of carbon neutral materials. Energy Environ. Sci. 5, 7781. doi:10.1039/ c2ee03455g

Schaef, H. T., and McGrail, B. P. (2009). Dissolution of Columbia River Basalt under mildly acidic conditions as a function of temperature: experimental results relevant to the geological sequestration of carbon dioxide. Appl. Geochem. 24, 980-987. doi:10.1016/j.apgeochem.2009.02.025

Sissmann, O., Daval, D., Brunet, F., Guyot, F., Verlaguet, A., Pinquier, Y., et al. (2013). The deleterious effect of secondary phases on olivine carbonation yield: insight from time-resolved aqueous-fluid sampling and FIB-TEM characterization. Chem. Geol. 357, 186-202. doi:10.1016/j.chemgeo.2013.08.031

Swanson, E. J., Fricker, K. J., Sun, M., and Park, A.-H. A. (2014). Directed precipitation of hydrated and anhydrous magnesium carbonates for carbon storage. Phys. Chem. Chem. Phys. 16, 23440-23450. doi:10.1039/C4CP03491K

Zevenhoven, R., Fagerlund, J., Björklöf, T., Mäkelä, M., and Eklund, O. (2014). Carbon dioxide mineralisation and integration with flue gas desulphurisation applied to a modern coal-fired power plant. J. Energy Power Eng. 8, 431-447.

Zevenhoven, R., Fagerlund, J., and Songok, J. K. (2011). $\mathrm{CO}_{2}$ mineral sequestration: developments toward large-scale application. Greenhouse Gases Sci. Technol. 1, 48-57. doi:10.1002/ghg3.7

Zhao, H., Park, Y., Lee, D. H., and Park, A. H. A. (2013). Tuning the dissolution kinetics of wollastonite via chelating agents for $\mathrm{CO}_{2}$ sequestration with integrated synthesis of precipitated calcium carbonates. Phys. Chem. Chem. Phys. 15, 15185-15192. doi:10.1039/c3cp52459k

Conflict of Interest Statement: The author declares that the research was conducted in the absence of any commercial or financial relationships that could be construed as a potential conflict of interest.

Copyright (c) 2016 Gadikota. This is an open-access article distributed under the terms of the Creative Commons Attribution License (CC BY). The use, distribution or reproduction in other forums is permitted, provided the original author(s) or licensor are credited and that the original publication in this journal is cited, in accordance with accepted academic practice. No use, distribution or reproduction is permitted which does not comply with these terms. 